16. Grime J.P. Plant strategies and vegetation processes // Chichester: Whiley and Sons, 1979. 222 p.

17. Комарова Т.А. К вопросу о закономерностях вторичных сукцессий в лесах Южного Сихотэ-Алиня // Динамические процессы в лесах Дальнего Востока. Владивосток: ДВНЦ АН СССР, 1984. С. 21-36.

18. Глушко С.Г., Прохоренко Н.Б. Лесоводственные свойства лесообразующих пород // Вестник Казанского ГАУ. 2014. № 3 (33). С. 120-122.
Опыт биоиндикации современных лесов в Татарстане..

19. Порфирьев В.С. Тёмнохвойно-широколиственные леса северо-востока Татарии // Учёные записки Казанского государственного педагогического института. Факультет естествознания. Казань: Татгосиздат, 1950. Вып. IX. C. 47-119.

20. Глушко С.Г. Значение рубок для воспроизводства хвойно-широколиственных лесов Среднего Поволжья // Вестник Казанского государственного аграрного университета. 2014. № 1 (31). С. 108-111.

\title{
BIOINDICATION EXPERIENCE IN FORESTS IN TATARSTAN NOWADAYS
}

(C) 2018

Glushko Sergei Gennadievich, candidate of agricultural sciences, associate professor of Forest Assessment and Forestry Economics Department Kazan State Agrarian University (Kazan, Russian Federation)

Prokhorenko Nina Borisovna, candidate of biological sciences, associate professor of Botany and Plant Physiology Department Kazan (Volga Region) Federal University (Kazan, Russian Federation)

Abstract. Anthropogenic impact led to the destruction of forests and the destruction of a significant part of them in different regions. The process of destruction over a large area causes the new natural conditions forming. Thus, it is important to find the new methods to assess forests and forest conditions. The use of data regarding dominant, edifying, differential plant species allows assessing forest growing conditions at certain stages of community development. The results of such studies can be used for the purposes of short-term forest planning. The new research materials on the life strategy of forest plants and forest communities in general are important to do a long-term forecast of the dynamics of forest-growing conditions. Complex characteristics of plant behavior or their life strategy reflects the process of adaptation of vegetation to the emerging forest-growing conditions. The authors analyze the possibility of determining the natural conditions by the features of the life strategy of individual forest-forming species (on the example of forests of the Republic of Tatarstan). The type of the vital strategy of tree species was revealed by the indicators of the course or energy of growth, as well as life expectancy. Critically important question concern researching the main forest forming breeds in Tatarstan, which adapt to the emerging conditions, and show signs of pioneering behavior or operational strategy.

Keywords: forest biota; forest conditions; sustainability of forests; plant life strategy; adaptation; forestry properties of trees.

УДК 581. 9 (476)

Статья поступила в редакцию 15.06.2018

\section{НОВЫЕ МЕСТОНАХОЖДЕНИЯ РЕДКИХ И НУЖДАЮЩИХСЯ В ОХРАНЕ СОСУДИСТЫХ РАСТЕНИЙ ВЫРАБОТАННЫХ ТОРФЯНЫХ МЕСТОРОЖДЕНИЙ (КИРОВСКАЯ ОБЛАСТЬ)}

(C) 2018

Егорова Наталья Юрьевна, кандидат биологических наук, старший научный сотрудник отдела экологии и ресурсоведения растений

Всероссийский научно-исследовательский институт охотничьего хозяйства и звероводства им. профессора Б.М. Житкова (г. Киров, Российская Федерация)

Егошина Татьяна Леонидовна, доктор биологических наук, профессор,

главный научный сотрудник отдела экологии и ресурсоведения; профессор кафедры экологии и зоологии Всероссийский научно-исследовательский институт охотничьего хозяйства и звероводства им. профессора Б.М. Житкова (г. Киров, Российская Федерация);

Вятская государственная сельскохозяйственная академия (2. Киров, Российская Федерация)

Аннотащия. В работе приведены материалы многолетнего обследования 6 выработанных торфяных месторождений, расположенных в центральной части Кировской области (Зуевский, Оричевский, Слободской, Кирово-Чепецкий районы). В результате проведенного исследования были выявлены новые местонахождения 10 редких и требующих охраны видов растений, включенных в Красные книги Кировской области и сопредельных регионов, а также видов, имеющих ограниченное распространение на территории области и обладающих узким экологическим ареалом: Gymnadenia conopsea, Dactylorhiza fuchsii, Epipactis helleborine, Epipactis atrorubens, Platanthera bifolia, Trichophorum alpinum, Botrychium multifidum, Dryopteris cristata, Thelipteris palustris, Huperzia selago. Представлены описания фитоценозов, в которых встречаются исследуемые виды. Показано появление в формирующихся в результате вторичного заболачивания новых сообществ типично болотных видов растений: Trichophorum alpinum, Drosera rotundifolia, Carex nigra, Eriophorum vaginatum, Parnassia palustris. Дана оценка состояния популяций редких видов. Отмечена способность изученных видов заселять искусственные ландшафты и антропогенно измененные фитоценозы, что демонстрирует проявление эксплерентной составляющей эколого-фитоценотической стратегии. Вторичные болотные ландшаф- 
ты могут выполнять функцию рефугиумов для видов, местообитания которых были утрачены вследствие техногенного воздействия.

Ключевые слова: редкие виды; Красная книга; выработанные торфяные месторождения; фитоценоз; болото; антропогенное воздействие; антропогенные биотопы; вторичное заболачивание; эколого-фитоценотическая стратегия; эксплерентная составляющая; рефугиум; Кировская область.

\section{Введение}

В настоящее время редкие и нуждающиеся в охране сосудистые растения Кировской области являются довольно активно изучаемой группой растений [1-8]. Это связано, прежде всего, со значительными изменениями антропогенного характера естественных местообитаний таких видов и их деградацией.

Хозяйственная деятельность человека, дальнейшее развитие промышленности неизбежно приводит к трансформации земельных угодий, одним из видов которой является появление значительных площадей выработанных торфяных месторождений (ВТМ). Отрицательное влияние таких нарушенных ландшафтов, восстанавливающихся естественным путем на протяжении длительного периода и мало пригодных для дальнейшего использования в практической деятельности человека, на природный комплекс велико. Появление нарушенных ландшафтов приводит к изменению растительного и почвенного покровов, водного и температурного баланса территории, к качественным и количественным изменениям состава почвы, поверхностных вод, водной и ветровой эрозии.

Кировская область является территорией интенсивного торфонакопления. В области зарегистрировано около 2 тыс. болот, общая площадь которых достигает 500 тыс. га. 10 болот имеют площадь свыше
5000 га каждое [9]. Болотные экосистемы имеют важное значение для сохранения биоразнообразия региона, в том числе и как местообитания важнейших ресурсообразующих и редких видов растений [10].

Площадь земель, вышедших из-под торфодобычи, в Кировской области составляет чуть более 370 тыс. га, из них лишь 34,7\% используются в качестве сельскохозяйственных земель, под лесопосадки [11] и другие хозяйственные цели, среди которых может быть, например, создание плантаций ягодников $[12 ; 13]$.

Целью настоящей работы было выявление и описание новых мест обитания редких и нуждающихся в охране сосудистых растений на выработанных торфяных месторождениях в пределах Кировской области.

\section{объекты и методы исследования}

В ходе полевых работ в Зуевском, Оричевском, Слободском, Кирово-Чепецком районах Кировской области в период с 2011 по 2017 гг. нами были выявлены новые места произрастания редких и требующих охраны видов растений, включенных в Красную книгу Кировской области (2014) (КККО) [14], а также виды, имеющие ограниченное распространение на территории области и обладающие узким экологическим ареалом.

Объектами исследования явились шесть выработанных торфяных месторождений (табл. 1).

Таблица 1 - Характеристика объектов исследования

\begin{tabular}{|c|l|l|c|c|}
\hline №п/п & \multicolumn{1}{|c|}{$\begin{array}{c}\text { Название } \\
\text { объекта }\end{array}$} & \multicolumn{1}{|c|}{ Местоположение } & Площадь, га & Тип залежи \\
\hline 1 & «Ляминское» & Зуевский район, Кировская область & 402 & низинный \\
\hline 2 & «Зенгино» & $\begin{array}{l}\text { Оричевский район, Кировская область, (левобережная } \\
\text { надпойменная терраса р. Вятка) }\end{array}$ & 6000,0 & $\begin{array}{l}\text { низинный и } \\
\text { переходный }\end{array}$ \\
\hline 3 & $\begin{array}{l}\text { «Ворошилов- } \\
\text { ский» }\end{array}$ & $\begin{array}{l}\text { Зуевский район, Кировская область, в 21 км на юго- } \\
\text { восток от п. Зуевка }\end{array}$ & 283,0 & $\begin{array}{l}\text { низинный - } \\
177 \text { га }\end{array}$ \\
\hline 4 & $\begin{array}{l}\text { «рокопьев- } \\
\text { ское» }\end{array}$ & $\begin{array}{l}\text { Слободской район, Кировская область, окр. } \\
\text { п. Октябрьский }\end{array}$ & 7500,0 & низинный \\
\hline 5 & «Перелаз» & $\begin{array}{l}\text { Кирово-Чепецкий район, Кировская область, в 7,5 км } \\
\text { на юго-восток от с. Просницы }\end{array}$ & 65,4 & низинный \\
\hline 6 & «Гадовское» & $\begin{array}{l}\text { Оричевский район, Кировская область (притеррасная } \\
\text { часть поймы р. Быстрица), окр. п. Юбилейный }\end{array}$ & 1635,0 & $\begin{array}{l}\text { низинный и } \\
\text { переходный }\end{array}$ \\
\hline
\end{tabular}

Описания растительных сообществ проводили согласно общепринятым геоботаническим подходам и методам [15-17] с подробной характеристикой видового состава (проективное покрытие, сомкнутость крон, обилие, высота растений, фенофаза, жизненность и др.) и физико-географических условий (увлажнение, экспозиция, рельеф местности и т.д.). Названия растений приведены по С.К. Черепанову [18].

\section{Результаты исследования и обсуждение}

В результате многолетних исследований обнаружены новые места произрастания редких и малочисленных видов, включенных в Красную книгу Кировской области и Приложение 2 «Список редких и уязвимых видов животных, растений и грибов, не внесенных в Красную книгу Кировской области
(КККО), но нуждающихся на территории области в постоянном контроле и наблюдении» [14]. Кроме того, выявлены виды, не включенные в данные документы (табл. 2), но имеющие ограниченное распространение на территории области, характеризующиеся низкой плотностью, включенные в списки редких и охраняемых видов сопредельных регионов.

Gymnadenia conopsea (L.) R. Br. - евразиатский, бореальный вид. В регионе исследований и на сопредельных территориях отмечен исследователями в составе фитоценозов заболоченных и пойменных лугов и зарослей кустарников, низинных болот, полян и опушек заболоченных лесов [19, с. 215; 20, с. 164]. Вид включен в Красные книги Кировской области $[14$, с. 224], Костромской области [21, с. 102], Республик Марий Эл [22, с. 52], Удмуртской Республи- 
ки [23, с. 306], а также в Приложение II к Конвенции CИТЕС. G. conopsea обнаружен в составе луговых фитоценозов различной степени увлажнения на трех из шести обследованных ВТМ (табл. 2): 1) гигрофитный осоково-таволговый луг (ВТМ «Перелаз»); 2) разнотравный луг (ВТМ «Ляминское»), 3) зарастающий ивами (Salix caprea, S. cinerea, S. myrsinifolia, S. pentandra) и ольхой серой (Alnus incana) гигрофитный разнотравый луг (ВТМ «Гадовское»). В избыточно увлажненных луговых фитоценозах формируются осоковые и злаковые сообщества. Здесь преобладают Calamagrostis langsdorffii, Elytrigia repens, Festuca pratensis, Bromopsis inermis, виды рода Carex (C. vesicaria, C. rostrata, C. nigra, C. lachenalii). Значительно участие в сложении травяного яруса данных фитоценозов Filipendula ulmaria. В более сухих условиях преобладают злаковые и злаковоразнотравные сообщества, в составе которых много обычных луговых видов: злаки (Poa pratensis, Alopecurus pratensis, $F$. pratensis) и большое количество видов сорного и лугового разнотравья (Tanacetum vulgare, Alchemilla vulgaris, Valeriana officinalis, Achillea millefolium, Galium mollugo, Lathyrus pratensis, Phleum pratense, F. ulmaria, Vicia cracca, Pimpinella saxifraga, Potentilla anserina, Dactylis glomerata, Veronica spicata, Ranunculus acris, Cirsium arvense, Vicia cracca, Plantago major, Pastinaca sativa, Taraxacum officinale, Artemisia vulgaris, Sonchus arvensis, Equisetum pratense, Hypericum maculatum, Geranium pratense и др).

Таблица 2 - Редкие и нуждающиеся в охране, постоянном наблюдении и контроле виды растений выработанных торфяных месторождений

\begin{tabular}{|c|c|c|c|c|}
\hline $\begin{array}{l}\text { № } \\
\Pi / \Pi\end{array}$ & Вид & Статус вида & Тип местообитания & $\begin{array}{l}\text { Выработанное } \\
\text { торфяное } \\
\text { месторождение }\end{array}$ \\
\hline \multicolumn{5}{|c|}{$\begin{array}{l}\text { Отдел. Magnoliophyta - Цветковые } \\
\text { Семейство Orchidaceae }\end{array}$} \\
\hline \multirow{3}{*}{1} & \multirow{3}{*}{$\begin{array}{l}\text { Gymnadenia } \\
\text { conopsea }(\mathrm{L} .) \mathrm{R} . \mathrm{Br} .\end{array}$} & \multirow{3}{*}{ КККО - III категория. } & $\begin{array}{l}\text { Гигрофитный осоково-таволговый } \\
\text { луг }\end{array}$ & «Перелаз» \\
\hline & & & Разнотравный луг & «Ляминское» \\
\hline & & & $\begin{array}{l}\text { Зарастающий ивами и ольхой серой } \\
\text { гигрофитный разнотравый луг }\end{array}$ & «Гадовское» \\
\hline 2 & $\begin{array}{l}\text { Dactylorhiza fuchsii } \\
\text { (Druce) Soo }\end{array}$ & КККО - III категория & Березняк разнотравно-вейниковый & $\begin{array}{l}\text { «Ворошилов- } \\
\text { ское» }\end{array}$ \\
\hline 3 & $\begin{array}{l}\text { Epipactis helleborine } \\
\text { (L.) Crantz }\end{array}$ & $\begin{array}{l}\text { Ограниченно распро- } \\
\text { страненный с низкой } \\
\text { плотностью }\end{array}$ & Березняк пушицевый & «Зенгино» \\
\hline 4 & $\begin{array}{l}\text { Epipactis atrorubens } \\
\text { (Hoffm.) Besser }\end{array}$ & $\begin{array}{l}\text { Ограниченно распро- } \\
\text { страненный с низкой } \\
\text { плотностью }\end{array}$ & Сероольшаник травяный & «Гадовское» \\
\hline 5 & $\begin{array}{l}\text { Platanthera bifolia } \\
\text { (L.) Rich. }\end{array}$ & Приложение № 2 КККО & $\begin{array}{l}\text { Сосняк сфагново-зеленомошно- } \\
\text { травяный }\end{array}$ & «Гадовское» \\
\hline \multicolumn{5}{|c|}{ Семейство Суреraceae } \\
\hline \multirow[t]{2}{*}{6} & \multirow[t]{2}{*}{$\begin{array}{l}\text { Trichophorum } \\
\text { alpinum (L.) Pers. }\end{array}$} & \multirow[t]{2}{*}{ КККО - III категория } & $\begin{array}{l}\text { Зарастающий пушицей участок отра- } \\
\text { ботанного торфяника, использован- } \\
\text { ный прежде под посевы многолетних } \\
\text { кормовых трав }\end{array}$ & «Зенгино» \\
\hline & & & $\begin{array}{l}\text { Сосняк зеленомошно-сфагново- } \\
\text { пушициевый }\end{array}$ & «Гадовское» \\
\hline \multicolumn{5}{|c|}{$\begin{array}{l}\text { Отдел Polypodiophyta - Папоротниковидные } \\
\text { Семейство Botrychiaceae }\end{array}$} \\
\hline \multirow[t]{2}{*}{7} & \multirow{2}{*}{$\begin{array}{l}\text { Botrychium multifi- } \\
\text { dum (S.G. Gmel) } \\
\text { Rupr. }\end{array}$} & \multirow{2}{*}{$\begin{array}{l}\text { Ограниченно распро- } \\
\text { страненный с низкой } \\
\text { плотностью }\end{array}$} & Сосняк грушанковый & $\begin{array}{l}\text { «Прокопьев- } \\
\text { ское» }\end{array}$ \\
\hline & & & Злаково-разнотравный луг & «Зенгино» \\
\hline \multicolumn{5}{|c|}{ Семейство Aspidiaceae } \\
\hline 8 & $\begin{array}{l}\text { Dryopteris cristata } \\
\text { (L.) A. Gray }\end{array}$ & $\begin{array}{l}\text { Ограниченно распро- } \\
\text { страненный с низкой } \\
\text { плотностью } \\
\end{array}$ & $\begin{array}{l}\text { Сосново-березово-еловый травяный } \\
\text { лес }\end{array}$ & «Зенгино» \\
\hline \multicolumn{5}{|c|}{ Семейство Thelipteridaceae } \\
\hline 9 & $\begin{array}{l}\text { Thelipteris palustris } \\
\text { Schott. }\end{array}$ & $\begin{array}{l}\text { Ограниченно распро- } \\
\text { страненный с низкой } \\
\text { плотностью }\end{array}$ & $\begin{array}{l}\text { Сосново-березово-еловый травяно- } \\
\text { зеленомошный лес }\end{array}$ & «Гадовское» \\
\hline \multicolumn{5}{|c|}{$\begin{array}{c}\text { Отдел Lycopodiophyta } \\
\text { Семейство Huperziaceae }\end{array}$} \\
\hline \multirow[b]{2}{*}{10} & \multirow[b]{2}{*}{$\begin{array}{l}\text { Huperzia selago (L.) } \\
\text { Bernh. Ex Scharank } \\
\text { et C. Mart. }\end{array}$} & \multirow[b]{2}{*}{ Приложение № 2 КККО } & Березняк травяный & «Зенгино» \\
\hline & & & $\begin{array}{l}\text { Ельник сфагново-зеленомошно- } \\
\text { травяный по краю мелиоративного } \\
\text { канала }\end{array}$ & «Гадовское» \\
\hline
\end{tabular}


Освоение данным видом антропогенно трансформированных ландшафтов отмечалось исследователями и ранее $[2 ; 19]$. G. conopsea в больших количествах произрастает на откосах водоема-отстойника ТЭЦ-5 (г. Киров) [19, с. 215], на зарастающем участке шламоотвала «Завода по обработке цветных металлов» (г. Киров) и выработанном карьере по добыче известняка (окр. д. Бакули Слободского района Кировской области) [2].

Dactylorhiza fuchsii (Druce) Soo евро-сибирский, бореальный вид, включен в Приложение 2 Красных книг Кировской области [14] и Республики Удмуртия [23, с. 449]. Отмечено произрастание D. fuchsii в регионе исследований в фитоценозах хвойных лесов, на лесных полянах, низинных болот [19, с. 213].

Вид найден на территории ВТМ «Ворошиловский» в березняке разнотравно-вейниковом (состав древостоя - 9Б1С, средний возраст древостоя 18 лет; сомкнутость крон - 0,4; высота древостоя 5,5-9,5 м). Состав наземной растительности до $80 \%$ представлен разнотравно-злаковыми группировками: Calamagrostis epigeios, Geum rivale, Tussilago farfara, Filipendula ulmaria, Angelica sylvestris, Potentilla anserina, Parnassia palustris, Chamaenerion angustifolium, Cirsium arvense, Mentha aquatica, Tanacetum vulgare, Achillea millefolium, Alchemilla vulgaris, Vicia cracca, Erigeron canadensis, Galium aparine, Lycopus europaeus, Leucanthemum vulgare, Artemisia vulgaris, Pilosella officinarum, Prunella vulgaris, Hypericum maculatum.

Epipactis helleborine (L.) Crantz. евразиатский неморальный вид, включен в Приложение 2 Красной книги Удмуртской Республики [23, с. 449]. В регионе исследований встречается редко, произрастая преимущественно по береговым склонам, сухим лесам различного породного состава, опушкам, полянам $[19$, с. 214]. Немногочисленные ценопопуляции E. helleborine были выявлены авторами ранее на старом зарастающем участке шламоотвала «Завода по обработке цветных металлов» (ОЦМ) (г. Киров) и на отвалах выработанного карьера по добыче известняка (окрестности д. Бакули, Слободской район, Кировская область) [2].

При исследовании ВТМ данный вид описан на зарастающем березой и сосной чеке ВТМ «Зенгино», имеет низкую численность популяции. Степень сомкнутости крон древостоя в фитоценозе составляет 0,3. Средний возраст древостоя варьирует от 20 до 25 лет. Средняя высота древостоя изменяется в пределах от 4,5 до 5,5 м. В травяно-кустарничковом ярусе описано 23 вида сосудистых растений. Наибольшее проективное покрытие характерно для Eriophorum vaginatum - $15 \%$, Juncus effusus - 10\%. Доля участия остальных видов не превышает 7\% - Calamagrostis epigeios, Achillea millefolium, Galium mollugo, Potentilla goldbachii, Parnassia palustris, Lycopus europeaus, Triglochin palustre и другие.

Epipactis atrorubens (Hoffm. Besser) евро-западноазиатский неморальный вид, включен в Красную книгу Костромской области [21, с. 98], Республики Марий Эл [22, с. 49], Республики Удмуртия [23, c. 304], в Приложение II к Конвенции СИТЕС. На территории Кировской области встречается редко, отмечен по береговым склонам и сухим хвойношироколиственным и широколиственным лесам. В естественных местообитаниях вид, по сравнению с антропогенно измененными экосистемами, образует небольшие по численности популяции или же уже не встречается, на что обращали внимание исследователи из других регионов [22, с. 49; 24], а также подтверждают и результаты исследования авторов [2].

На территории исследуемого ВТМ «Гадовское» E. atrorubens обнаружен в составе сероольшанника травяного, сформировавшегося по краю вала мелиоративного канала, перегороженного бобровой плотиной. Возраст древостоя - около 30 лет. В составе подлеска отмечены Salix caprea, S. cinerea, Frangula alnus, в травяном покрове преобладают Filipendula ulmaria, Geum rivale, Angelica sylvestris, Cirsium heterophyllum, Vicia sepium, Galium boreale, Lycopus europaeus.

Platanthera bifolia (L.) Rich. бореально-неморальный вид с широким евромалоазиатско-сибирским ареалом. Вид включен в Приложение 2 к КККО [14]. В регионе исследования встречается преимущественно по лесным полянам, опушкам, лесным дорогам, вырубкам, в сосновых лесах, в северной части области - в хвойных лесах зеленомошного типа. На территории исследуемых объектов ВТМ P. bifolia найдена в сосняке сфагново-зеленомошно-травяном (ВТМ «Гадовское»). В среднеполнотном и средневозрастном древостое фитоценоза доминирует $P$. sylvestris, в качестве примеси отмечены Picea $\times$ fennica и Betula pubescens. В травяном ярусе преобладают Parnassia palustris, Pyrola major, Ortilia secunda.

Для P. bifolia, как и других рассматриваемых представителей семейства Orchidaceae, отмечена способность заселять антропогенно измененные фитоценозы, что является проявлением эксплерентной составляющей эколого-фитоценотической стратегии [2].

Trichophorum alpinum (L.) Pers. циркумбореальный, бореальный вид. Внесен в Красные книги Кировской области [14, с. 245], Удмуртской Республики [23, с. 333]. В регионе исследования, как отмечено Е.М. Тарасовой [19, с. 222], вид встречается очень редко, предпочитая олиготрофные болота и выработанные торфяники. В Удмуртской Республике T. alpinum растет на сфагновых болотах, по берегам зарастающих озер, избыточно увлажненных и заболоченных лугах [23, с. 333], где может образовывать крупные скопления.

T. alpinum изучен на участках 2 ВТМ (ВТМ «Зенгино» и «Гадовское») при повторном заболачивании, где в условиях избыточного увлажнения появляются характерные для болот виды: Drosera rotundifolia, Carex nigra, Eriophorum vaginatum, Parnassia palustris. T. alpinum характеризуется достаточно высоким обилием $\left(\mathrm{Cop}^{1}\right)$ и равномерным распределением по участку вторичного заболачивания, при общей величине проективного покрытия исследуемого фитоценоза - 45\%. Фитоценоз ВТМ «Зенгино» был полностью открытым, ВТМ «Гадовское» характеризовался наличием изреженного низкорослого древостоя из Pinus sylvestris и Betula pubescens. Ценопопуляции на территории обследованных ВТМ являются многочисленными и устойчивыми. Мониторинг численности популяции вида не выявил ее снижения за последние 20 лет.

Botrychium multifidum (S.G. Gmel) Rupr. циркумбореальный, плюризональный реликтовый вид. 
Включен в Красные книги Костромской области [21, c. 47], Республики Марий Эл [22, с. 164], Удмуртской Республики [23, с. 460]. В регионе исследования встречается редко: на лесных полянах, в сосновых лесах, зарастающих вырубках. В результате исследования выявлены два типа местообитания B. multifidum:

1) разнотравно-злаковый луг (ВТМ «Зенгино»). В травяном покрове отмечено 42 вида сосудистых растений, наибольшее покрытие приходится на злаки $60 \%$ и более - Calamagrostis langsdorffii, Calamagrostis epigeios, Phleum pratense, Elytrigia repens, Festuca pratensis. Разнотравье формируют такие виды как Achillea millefolium, Galium mollugo, Rumex crispus, Vicia cracca, Linaria vulgaris, Hypericum maculatum, Veronica chamaedrys, Melandrium album и другие.

2) Сосняк грушанковый - 15 -летняя культура сосны с естественным возобновлением березы (ВТМ «Прокопьевское») [25]. Возраст Pinus sylvestris 9 лет, Betula pubescens - 12 лет. В травяном ярусе доминирует Pyrola rotundifolia. С меньшим обилием отмечены такие виды, как Chamaenerion angustifolium, Fragaria vesca, Orthilia secunda, Tussilago farfara, Antennaria dioica, Poa nemoralis, Taraxacum officinale, Calamagrostis neglecta, Hieracium pilosella. Моховый покров представлен по кочкам - Polytrichum commune, Pleurozium shreberi.

Dryopteris cristata (L.) A. Gray циркумбореальный, бореально-неморальный вид. Свойственными местами произрастания для него являются переходные и низинные болота, заболоченные леса, сырые ельники, берега водоемов. Вид обнаружен и описан в березняке грушанковом (ВТМ «Зенгино») (состав древостоя - 10Б, средний возраст древостоя - 25 лет; сомкнутость крон - 0,8; высота древостоя - 8,510,5 м). Общее проективное покрытие травянокустарничкового яруса составляет $15 \%$, доминирует - Pyrola rotundifolia, с несколько меньшим обилием присутствуют Fragaria vesca, Viola mirabilis, Calamagrostis epigeios, Equisetum sylvaticum, Epilobium palustre, менее $1 \%$ доля участия таких видов как Orthilia secunda, Galium mollugo, Equisetum fluviatile, Hieracium umbellatum, Geum rivale, Rumex acetosella, Prunella vulgaris. Мохово-лишайниковый покров не выражен.

Thelipteris palustris Schott. циркумбореальный, бореальный вид. Типичными местообитаниями являются переходные и низинные болота, заболоченные леса, берега водоемов. Вид обнаружен в сосновоберезово-еловом травяно-зеленомошном лесу (ВТМ «Гадовское»).

Huperzia selago (L.) Bernh. Ex Scharank et C. Mart. циркумбореальный, арктобореальный вид, включен в Красные книги Костромской области [21, с. 51], Республики Марий Эл [22, с. 170], в Приложение № 2 к КККО и нуждается на территории области в постоянном контроле и наблюдении [14]. Вид описан в березняке травяном (ВТМ «Зенгино») и ельнике сфагново-зеленомошно-травяном по краю мелиоративного канала (ВТМ «Гадовское»). Древесный ярус в березняке травяном формирует Betula pubescens, отмечены единичные экземпляры Pinus sylvestris. Coмкнутость крон древостоя - 0,4, средний возраст 15-17 лет, средняя высота - 3,5-5,0 м. Подрост сла- бый из Betula pubescens, Pinus sylvestris, Picea $\times$ fennica. Подлесок представлен Sorbus aucuparia, Salix cinerea, Frangula alnus. В травяно-кустарничковом ярусе (общее проективное покрытие около 65\%) доминируют Pyrola rotundifolia, Eriophorum vaginatum, Carex nigra, Agrostis tenuis, Potentilla anserina, c меньшим обилием отмечены Galium mollugo, Potentilla goldbachii, Prunella vulgaris, Juncus effuses, Parnassia palustris, Equisetum pratense, Mentha aquatica, Viola rupestris, Fragaria vesca, Campanula patula, Lycopodium annotinum, Poa palustris, Odontites vulgaris, Lycopus europeaus, Euphrasia fennica. Моховый покров не сплошной (20\%) формируют Polytrichum juniperinum, Dicranum undulatum, в виде отдельных пятен.

\section{Заключение}

Антропогенный прессинг оказывает значительное влияние на растительный покров области. Для большинства видов болотных экосистем основными лимитирующими факторами существования являются узкая экотопологическая приуроченность, нарушения гидрологического режима и антропогенные воздействия (разработка торфяников, мелиорация). В то же время чеки выработанных торфяных месторождений являются своеобразными автономными комплексами, в которых сохраняются условия для самовосстановления после прекращения хозяйственного использования, благодаря процессам вторичного заболачивания участков торфяных месторождений, эвтрофикации. В результате этого наблюдается появление в формирующихся новых сообществах типично болотных видов, таких как Trichophorum alpinum, Drosera rotundifolia, Eriophorum vaginatum, некоторых представителей сем. Orchidaceae (Gymnadenia conopsea, Dactylorhiza fuchsia и др.). Способность растений заселять антропогенно измененные ландшафты является проявлением эксплерентной составляющей эколого-фитоценотической стратегии. Для некоторых видов сем. Orchidaceae это было показано ранее [2]. Исследование редких видов выработанных торфяных месторождений позволило установить наличие эксплерентной составляющей и у представителей других таксономических групп (отд. Magnoliophyta: сем. Cуреraceae; отд. Polypodiophyta: сем. Aspidiaceae, сем. Thelipteridaceae; отд. Lycopodiophyta: сем. Huperziaceae). Исходя из этого, можно рассматривать вторичные болотные ландшафты в качестве рефугиумов для видов, местообитания которых были утрачены вследствие техногенного воздействия.

\section{Список литературы:}

1. Чиркова Н.Ю. Оценка экологического состояния популяций Cypripedium calceolus L. в Кировской области // V Ботанічні читання памяти Й.К. Пачоського. Збірка тез доповідей міжнародноі конференціі, Херсон, 28.09-01.10.2009р. / відповідальний редактор М.Ф. Бойко. Херсон: Айлант, 2009. С. 121.

2. Чиркова Н.Ю., Егошина Т.Л. Проявление черт эксплерентности некоторых видов семейства Orchidaceae Juss. в антропогенно измененных экосистемах // Охрана и культивирование орхидей: материалы IX междунар. конф. (26-30 сентября 2011). М.: Товарищество научных изданий КМК, 2011. С. 466-468.

3. Баранова О.Г., Егошина Т.Л., Чиркова Н.Ю., Ярославцев А.В. Новые местонахождения видов семейства Орхидных (Orchidaceae Juss.) в Кировской 
области // Охрана и культивирование орхидей: мат-лы IX междунар. конф. (26-30 сентября 2011). М.: Товарищество научных изданий КМК, 2011. С. 51-52.

4. Чиркова Н.Ю., Сулейманова В.Н., Егошина Т.Л., Лугинина Е.А. Эколого-фитоценотическая и демографическая характеристика ценопопуляций Cypripedium calceolus L. в условиях южнотаежных лесов Кировской области // Вестник ТвГУ. Серия «Биология и экология», 2011. Вып. 24. № 32. С. 117-126.

5. Капустина Н.В., Егорова Н.Ю., Егошина Т.Л., Рябова Е.В. Состояние ценопопуляций некоторых представителей семейства Orchidaceae на территории ГПЗ «Былина» // Актуальные проблемы региональной экологии и биодиагностика живых систем: материалы XI всерос. науч.-практ. конф. - выставки инновационных экологических проектов с междунар. участием (г. Киров, 26-28 ноября 2013 г.). Киров: Изд-во ООО «Веси», 2013. С. 478-482.

6. Егорова (Чиркова) Н.Ю., Сулейманова В.Н., Егошина Т.Л. Состояние ценопопуляций Platanthera bifolia (Orchidaceae) в Кировской области // Растительные ресурсы. 2014. Т. 50, № 3. С. 398-414.

7. Капустина Н.В., Егорова Н.Ю., Егошина Т.Л. Состояние ценопопуляций Dactylorhiza fuchsii (Druce) Soо на территории ГПЗ «Былина»// Вестник Оренбургского государственного университета. 2015. № 6. C. 17-24.

8. Егорова Н.Ю., Егошина Т.Л., Сушенцов О.Е. Популяционная изменчивость Pulsatilla patens s. 1. (Ranunculaceae) в бассейне реки Вятка // Растительные ресурсы. 2017. Т. 53. № 2. С. 237-254.

9. Уланов А.Н. Использование торфяных ресурсов Кировской области // Рациональное использование торфяных месторождений: материалы междунар. науч.-практ. конф., посв. 90-летию основания Кировской лугоболотной опытной станции: сб. научных трудов. Киров: Кировская лугоболотная опытная станция, 2008. С. 42-48.

10. Егошина Т.Л. О необходимости охраны и изучения болот в Кировской области // Рациональное природопользование на рубеже веков. Томск, 2000. C. $47-48$.

11. Леса Кировской области / под ред. А.И. Видякина и др. Киров, 2008. 400 с.

12. Egoshina T.L., Luginina E.A. Vaccinium vitisidaea and Oxycoccus palustris in natural Populations and Culture in Taiga Zone of Russia // Acta horticulturae et regiotecturae. 2007. № 10. P. 57-61.

13. Чиркова Н.Ю., Сулейманова В.Н. Оценка возможностей введения в культуру и перспективы культивирования хозяйственно ценных видов дикорастущих ягодников Кировской области. Вестник ОГУ: Естественные науки. 2010. № 5 (111). С. 115-119.

14. Красная книга Кировской области. Киров, 2014. $336 \mathrm{c}$.

15. Методика полевых геоботанических исследований. М.-Л.: Наука, 1983. 216 с.

16. Методы исследований болотных экосистем таежной зоны. Л.: Наука, 1991. 128 с.

17. Методы изучения лесных сообществ. СПб.: НИИ Химии СПбГУ, 2002. 240 с.

18. Черепанов С.К. Сосудистые растения России и сопредельных государств (в пределах бывшего СССР). СПб., 1995.992 с.

19. Тарасова Е.М. Флора Вятского края. Ч. 1. Сосудистые растения. Киров: ОАО «Кировская областная типография», 2007. $440 \mathrm{c.}$

20. Баранова О.Г., Пузырев А.Н. Конспект флоры Удмуртской Республики (сосудистые растений). Ижевск: Изд-во АНО «Ижевский институт компьютерных исследований», 2012. 211 с.

21. Красная книга Костромской области. 2009. Кострома. 387 с.

22. Красная книга Республики Марий Эл. 2012. Том «Растения. Грибы». Йошкар-Ола. 324 с.

23. Красная книга Удмуртской Республики. Чебоксары. 2012. 458 с.

24. Телеганова В.В., Решетникова Н.М., Хомутовский М.И., Воронкина Н.В., Шмытов А.А., Крылов А.В. Роль известняковых карьеров в сохранении и адвентизации флоры Калужской области // Труды регионального конкурса проектов фундаментальных научных исследований. Вып. 20. Калуга: Калужский государственный институт развития образования, 2015. C. 195-205.

25. Албегова А.В., Егошина Т.Л., Савиных Н.П. и др. Оценка пригодности выработанных участков торфяного месторождения «Прокопьевское» для создания плантаций ягодных растений // Современные проблемы природопользования, охотоведения и звероводства: матер. межд. науч.-практ. конф. Киров, 2012. C. 371-372.

\section{NEW LOCATIONS OF RARE VASCULAR PLANT SPECIES ON CUT-OVER PEAT LANDS (ON THE EXAMPLE OF KIROV REGION)}

(C) 2018

Egorova Natalya Yurievna, candidate of biological sciences, senior researcher of Ecology and Plant Resources Department

Professor Zhitkov Russian Research Institute of Game Management and Fur Farming (Kirov, Russian Federation)

Egoshina Tatiana Leonidovna, doctor of biological sciences, professor,

chief researcher of Ecology and Plant Resources Department; professor of Ecology and Zoology Department

Professor Zhitkov Russian Research Institute of Game Management and Fur Farming (Kirov, Russian Federation); Vyatka State Agricultural Academy (Kirov, Russian Federation)

Abstract. The paper presents the investigation data of 6 cut-over peat lands in central area of Kirov Region (on the example of Zuev, Orichev, Slobod, Kirov and Chepez areas). The authors found the new locations of 10 rare plant species enlisted in the regional Red Book and species that have limited distribution in a region or have narrow ecological range (Gymnadenia conopsea, Dactylorhiza fuchsii, Epipactis helleborine, Epipactis atrorubens, Platanthera bifolia, Trichophorum alpinum, Botrychium multifidum, Dryopteris cristata, Thelipteris palustris, Huperzia selago). They also describe the process of phytocoenoses. The study shows the development of new typical boggy plant societies as a result of secondary bogging (on the example of Trichophorum alpinum, Drosera rotundifolia, 
Carex nigra, Eriophorum vaginatum, Parnassia palustris). The paper estimates the state of rare species populations. The authors analyze the ability of the species to inhabit artificial landscapes and anthropogenically modified phytocoenoses. That shows an explerent component of ecological-phytocoenotic strategy. Secondary boggy landscapes can play the role of refugiums for the species which habitats were lost due to industrial impact.

Keywords: rare species; Red Book; cut-over peat land; phytocoenoses; bog; anthropogenic impact; secondary bogging; ecological-phytocoenotic strategy; refugiums; Kirov Region.

\section{ВЛИЯНИЕ РЕСУРСОСБЕРЕГАЮЩИХ СПОСОБОВ ОСНОВНОЙ ОБРАБОТКИ ЧЕРНОЗЕМА ОБЫКНОВЕННОГО НА ПОКАЗАТЕЛИ ОБЩЕЙ БИОЛОГИЧЕСКОЙ АКТИВНОСТИ И УРОЖАЙНОСТЬ ЗЕРНОВЫХ КУЛЬТУР} (C) 2018

Заушинцена Александра Васильевна, доктор биологических наук, профессор кафедры ботаники Кемеровский государственный университет (2. Кемерово, Российская Федераиия)

Романов Василий Николаевич, доктор сельскохозяйственных наук, ведущий научный сотрудник отдела агротехнологий

Красноярский научно-исследовательский институт сельского хозяйства, Федеральный исследовательский иентр «Красноярский научный центр СО РАН» (2. Красноярск, Российская Федераиия)

Кожевников Николай Владимирович, аспирант кафедры ботаники

Кемеровский государственный университет (2. Кемерово, Российская Федераиия)

Аннотация. В настоящее время широкое распространение получают ресурсосберегающие технологии возделывания зерновых культур. В связи с недостаточным научным обеспечением необходимо исследование новых технологий обработки в различных почвенно-климатических условиях. В статье анализируется влияние технологических приемов обработки почвы на показатели общей биологической активности чернозема обыкновенного Красноярской лесостепи. Наибольшей интенсивностью почвенного дыхания и целлюлозолитической активности характеризуется почва целинного варианта. Многолетняя обработка чернозема обыкновенного опытного поля привела к снижению общей биологической активности в среднем на 30,5-33,5\%. Внедрение новых технологий возделывания полевых культур, основанных на прямом посеве и минимальной обработке почвы, поддерживает высокий уровень общей биологической активности в течение вегетационного периода. Наибольшая биологическая активность наблюдается при минимальной обработке почвы. Значительное влияние на показатели общей биологической активности оказали гидротермические условия. Повышенная влажность почвы вызвала значительное увеличение целлюлозоразлагающей активности на 27-38\% и почвенного дыхания на 17-24\%. При увеличении влажности почв более выраженно проявилось влияние обработки почвы. Возделываемые культуры не оказали существенного влияния на общую биологическую активность. Использование нулевой обработки привело к приросту урожайности яровой пшеницы на 0,93 ц/га и снижению урожайности овса и ячменя. На варианте минимальной обработки отмечается небольшое снижение урожайности ячменя на 0,25 ц/га и пшеницы на 0,44 ц/га. Снижение производственных затрат при использовании ресурсосберегающих технологий обработки приводит к повышению прибыли и уровня рентабельности. Наиболее высокий уровень рентабельности показали варианты прямого посева при выращивании пшеницы $(139,58 \%)$ и овса $(142,24 \%)$.

Ключевые слова: минимальная обработка почвы; прямой посев; чернозем обыкновенный; зерновые культуры; микробиологическая активность; целлюлозолитическая активность; дыхание почвы; рентабельность; Красноярская лесостепь.

\section{Введение}

В современной мировой сельскохозяйственной практике на смену традиционным интенсивным технологиям возделывания зерновых культур приходят ресурсосберегающие системы минимальной и нулевой обработки почвы. В связи с обострением экологических проблем и падением уровня плодородия агрогенных почв возникла необходимость проведения исследований по оценке современных приемов воспроизводства почвенного плодородия.

Обработка почв - важнейший элемент технологии возделывания культурных видов растений, от которого зависят факторы почвенного плодородия. Изменяя структуру и строение пахотного горизонта, механическая обработка изменяет тепловой и водновоздушный режим почвы, оказывает влияние на микробиологическую активность и круговорот питательных элементов $[1 ; 2]$.
Разрабатывая рациональные и экологически безопасные технологии обработки, необходимо учитывать их влияние на биологические свойства почвы, характеризующие состояние почвенного плодородия [3; 4]. Биологическая активность, благодаря высокой чувствительности и устойчивости, объективно отражает изменения, происходящие в экологическом состоянии агрогенных почв [5]. В нашей работе биологическую активность оценивали по интенсивности выделения углекислого газа и скорости разложения клетчатки, а также была определена микробиологическая активность.

В качестве комплексного показателя биологической активности почвы наиболее часто рассматривают целлюлозолитическую активность [6]. Процессы разложения клетчатки в почве позволяют судить об интенсивности биохимических процессов и биологическом круговороте элементов питания, а следо- 